\title{
EXTRACTION THE ESSENTIAL OIL FROM JUNIPERUS SABINA L. GROWING IN THE REPUBLIC OF MOLDOVA
}

\section{Elisovetcaia Dina}

Institute of Genetics, physiology and plant protection ASM, Chisinau, Republic of Moldova

\section{ЭКСТРАКЦИЯ ЭФИРНОГО МАСЛА ИЗ JUNIPERUS SABINA L., ПРОИЗРАСТАЮЩЕГО В РЕСПУБЛИКЕ МОЛДОВА}

\section{Елисовецкая Дина}

Received 26. 6. 2017
Revised 28. 6. 2017

Juniperus sabina L. (Cupressaceae Gray), savin juniper or savin, is a perennial shrub, native to the mountains of central and southern Europe and western and central Asia, from Spain to eastern Siberia. The extracts and essential oil from Juniperus sabina find application in the different directions, including medicine, food industry and agriculture. In the Republic of Moldova the species Juniperus sabina is widely cultivated and used for the landscape gardening and planting of greenery. As a result of annual green pruning of existing in the republic juniper plantations, it is possible to obtain at least 2-3 tons of raw material, extracts of which possess biological activity. The biological activity of essential oil from species of Juniperus sabina growing in Moldova has not been sufficiently studied at the present time, and, moreover, there are no data on the quantitative content of essential oil in it. Therefore, the aim of the study was a comparative analysis of the quantitative content of essential oil in fresh and dried plant materials of the Juniperus sabina, growing in the conditions of the Republic of Moldova. Extraction oil from plant raw materials was performed according to a hydrodistillation method (HD) in which the essential oils are evaporated by heating a mixture of water and plant materials at atmospheric pressure, followed by the liquefaction of the vapors in a condenser (reflux) and collection in receiving vessel Ginsberg. It has been found that the amount of essential oil extracted from the plant J. sabina significantly depended on the extraction time $(p \leq 0.05)$ and was average from $1.47 \mathrm{ml}$ for 1 hour of extraction to $2.16 \mathrm{ml}$ for 2.5 hours (from $100 \mathrm{~g}$ dried plant materials in the recount of the absolutely dry weight of the raw materials). In the fresh plant materials of the Juniperus sabina amount of essential oil also significantly depended on the extraction time $(p \leq 0.05)$ and reached from 1.0 to $2.86 \mathrm{ml}$ (from $100 \mathrm{~g}$ fresh plant materials in the recount of the absolutely dry weight of the raw materials). As a result, in the needles (acerouse leaf) of Juniperus sabina, growing in the Republic of Moldova, contains not less than $1.1 \%$ of essential oil, which is fullest extracted both from fresh and from dried raw materials, during 2.5 hours.

Keywords: essential oil; Juniperus sabina; Savin juniper; extraction time; plant extract; dried and fresh plant material 


\section{Введение}

Родиной можжевельника казацкого (Juniperus sabina L. (Cupressaceae Gray)) считается горный массив Центральной и Южной Европы, восточная и центральная Азия, Сибирь и Кавказ. Растение предпочитает каменистые склоны, скалы в степном и лесостепном поясах гор.

В настоящее время вид Juniperus sabina натурализовался в Юго-Западной, Центральной и ЮгоВосточной Европе (кроме Севера), Северной Африке, в Крыму, на Кавказе, в России на Алтае и Урале, в Иране, Казахстане, Кыргызстане, Турции, Монголии, Северном и Северо-Западном Китае (Farjon, 2013; Adams, 2014; Аёшина и Величко, 2004; Щербаков и др., 2014).

Можжевельник казацкий широко культивируется как в декоративных целях, так и в качестве почвопокровного и укрепляющего растения. Среди культивируемых сортов наиболее распространены Blue Danube, Erecta, Mas, Rockery Gem, Tamariscifolia, Variegata, Arcadia, Thomsen и др. Это естественно редкий вид, приуроченный к биотопам с эдафической сухостью. Размножается семенами и вегетативно укоренением ветвей.

Обычно Juniperus sabina - низкорослый, стелющийся кустарник от 1,5 до 3,5 м высоты с часто расположенными простертыми ветвями до 1,5 м длины. В природе может произрастать в жизненной форме дерева с изогнутыми стволами и достигать 4 м в высоту. Двудомное, реже однодомное, многолетнее растение (Farjon, 2013). Хвоя у можжевельника казацкого двух типов: у молодых растений и на затенённых ветвях игловидная, прямостоячая, заострённая, 4 - 6 мм длиной, сверху синевато-зелёная, мягкая, с чётко выделяющейся срединной жилкой; у взрослых растений хвоя чешуевидная, расположенная черепитчато. Хвоинки 1,5 - 2(3) мм длиной, 0,5 - 1 мм шириной, эллиптические, заостренные, почти до 2/3 длины, сросшиеся со стеблем. Молодые стебли обычно тоньше 1 мм. Кора: красно-коричневая отслаивающаяся. Микростробилы (мужские шишечки) 2-3 мм длиной, 1,5 - 2 мм шириной, овальные, одиночные на концах веточек. Макростибулы (женские шишечки) шаровидные или яйцевидные, более 5 мм длиной, плодоножка изогнутая. Семеношение начинается с 8 лет, нерегулярное. Шишкоягоды поникающие, мелкие (5 - 7 мм), буро-чёрные с сизым налётом, округло-овальные, большей частью двусемянные (могут содержать от 1 до 6 семян). Семена: без заметного хилума, продолговато-трехгранные, желто-бурые до 5 мм длиной (2 - 4,5 мм в ширину) с очень твердой скорлупой (Schulz et al., 2005; Medicinal plants in Mongolia, 2013; Farjon, 2013; Adams, 2008, 2014; Семенютина, 2014; Брагинец, 2016).

Начало вегетации - март-апрель; начало цветения - апрель-май, начало роста побегов первая декада апреля, фаза активного вегетативного роста июнь - июль; созревание шишко-ягод - вторая половина октября или весна следующего года; окончание роста хвои и побегов (окончание вегетационного периода) - вторая половина - конец октября (Козак, 1993; Семенютина и др., 2014; Брагинец, 2016). Можжевельник казацкий быстро разрастается в ширину, благодаря укоренению горизонтальных, лежащих на поверхности почвы ветвей и образует кусты до 5 - 7 м диаметром (Farjon, 2013). Благодаря этому свойству он подвергается в декоративных целях ежегодной обрезке боковых ветвей. Ранее нами было установлено, что в условиях Республики Молдова при ежегодной обрезке с 1 куста возможно получение минимум до 0,5 кг зеленой массы, а с 1 га возможно получение примерно 150 - 300 кг сухой массы растения для экстракции из нее биологически активных веществ (Елисовецкая и др., 2014).

Можжевельник с давних времен используется в народной медицине, ароматерапии, парфюмерии и пр. Из шишко-ягод изготавливают вино, водку, коньяк, пиво и джин. Из коры и плодов получают красители - зеленовато желтые и цвета хаки. Древесина идет на изготовление мебели, столярных изделий и высокопрочных нитей, из веток вяжут банные веники, а масло можжевельника служит в качестве иммерсионного, а также является главным компонентом лака для изготовления музыкальных инструментов. Благодаря богатому химическому составу из можжевельника получают препараты как медицинского назначения, 
обладающие, например, антисептической, цитостатической и противовирусной активностью, так и средства для борьбы с различными вредными видами насекомых (Носов, 2001; Аёшина и Величко, 2004; Farjon, 2005, 2013; Семенютина и др., 2014; Zhao et al., 2016; Nikolic et al., 2016).

Основные действующие вещества хвои и плодов можжевельника казацкого это эфирное масло сабиноль (2,5 - 4,8 \%), состоящее из третичного спирта сабинола (от 10 до 50 \% состава) и различных терпеновых соединений (до $30 \%$ состава).

Плоды, кроме эфирного масла, содержат до 40\% сахаров. В состав Juniperus sabina входят также горький гликозид пинопикрин, галловая кислота (которая превращается в пирогаллол), дубильные вещества, флавоноиды, смола, воск, витамин С, органические кислоты, кумарины, флавоноиды (до 2,13 \%), лигнаны (Аёшина и Величко, 2004; Мырзагалиева, Медеубаева, 2014; Новиков и др., 2014).

В настоящее время в медицине, пищевой и ликероводочной промышленности наиболее широкое применение нашли плоды можжевельника. По этим причинам количественное содержание и качественный состав эфирных масел из плодов растений Juniperus sabina достаточно детально изучаются во всем мире (Писарев, 2005; Мырзагалиева и др., 2014; Щербаков и др., 2014; Hesham et. al., 2016). Однако ежегодно собираемый урожай плодов с имеющихся посадок и природных плантаций не покрывает растущей потребности в эфирном масле, а также других биологически активных веществах из можжевельника. Кроме того, известно, что количественный и качественный состав растений существенно зависит от мест и условий произрастания. Поэтому цель настоящих исследований состояла в сравнительном анализе количественного извлечения эфирного масла из свежего и высушенного растительного материала Juniperus sabina, произрастающего на территории Республики Молдова.

\section{Материалы и методы}

Объектами исследований служили растения вида Juniperus sabina, произрастающие в Центральной зоне Республики Молдова (рис. 1). Растения были собраны во второй декаде мая (координаты сбора 46 57' 44.3" N 28 53' 16.9" Е) путем обрезки 30 - 50 см отросших боковых ветвей. Идентификация растения Juniperus sabina была проведена с помощью специалистов Института Ботанического сада АНМ и Института Исследований и менеджемента лесных насаждений, Кишинэу (Elisovetskaya et. al., 2014).
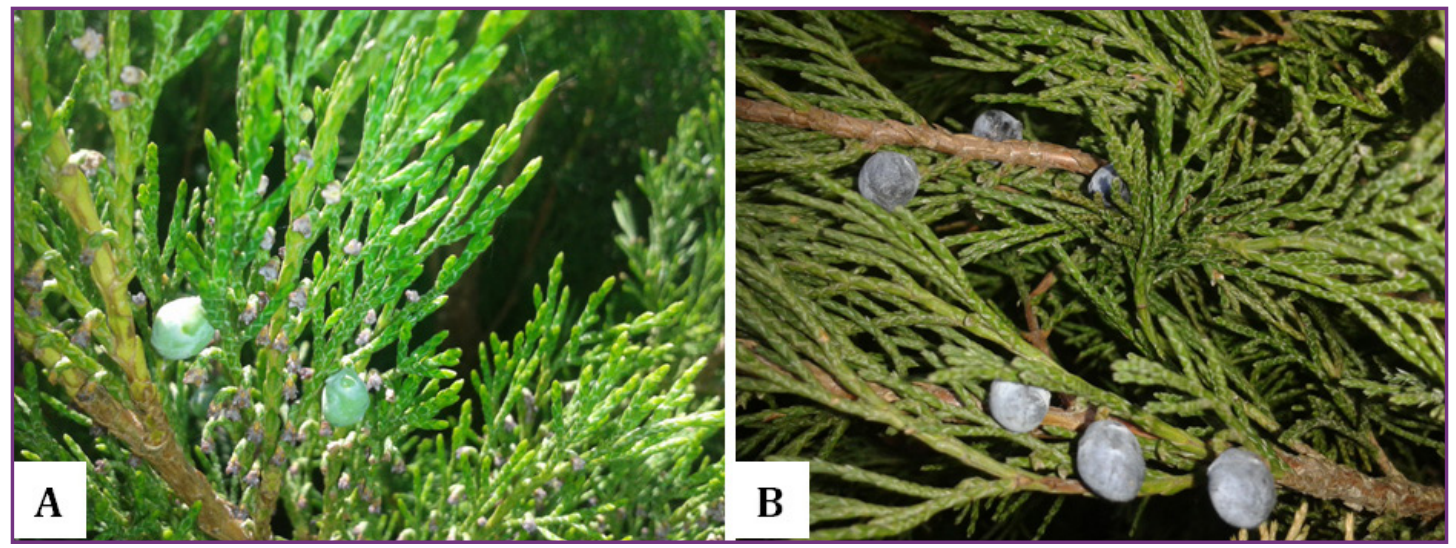

Рисунок 1 Juniperus sabina L., произрастающий в Республике Молдова (май 2017) А - цветение; В - созревание плодов

Figure 1 Juniperus sabina L., growing in the Republic of Moldova (May 2017) A - flowering; B - fruit ripening 
После сбора часть растений измельчали секатором до частиц длиной примерно 2 - 5 мм и использовали в свежем виде. Влажность собранного сырья составляла 65 \%. Остальные растения взвешивали и тонким слоем сушили (до достижения влажности 12 \%) в хорошо проветриваемом помещении вдали от источников тепла и прямых солнечных лучей при комнатной температуре в течение примерно двух недель. Сухое сырье измельчали на электрической лабораторной мельнице (Тип МРП-1, асинхронный двигатель, МСХ СССР НПО «Агроприбор», 1987). в течение 1 - 2 мин и просеивали на сите с размером отверстий 2 мм. Влажность $(W)$ растительного сырья определяли согласно стандартной методике (ОФС.1.5.3.0007.15) и вычисляли в процентах по формуле 1:

$$
W=\frac{\left(m-m_{1}\right) \cdot 100}{m}
$$

где: $\quad$ W - влажность растительного сырья в процентах; $m$ - масса до высушивания, г; $m_{1}$ - масса после высушивания, г

Извлечение эфирного масла проводили методом гидродистилляции (Hesham et.al., 2016) путем перегонки навески сырья (200 г для свежего и 100 г для сухого растения) с очищенной водой (воду добавляли в соотношении сырье : растворитель $1: 6$ ) в 1 - 2 литровой колбе с обратным холодильником (рис. 2). Эфирное масло собирали в подвешенный свободно в колбе приемник Гинсберга. Так как приемник не был откалиброван, его после перегонки извлекали, охлаждали на воздухе до комнатной температуры, отделяли эфирное масло с помощью микропипеток и количественно переносили его в мерные пробирки с ценой деления 0,02 мл Колбу с содержимым нагревали на газовой электроплитке или электроплитке с закрытой спиралью и регулятором мощности нагрева и кипятили в течение одного часа, двух часов, трех часов и более (до прекращения увеличения объема эфирного масла, определяемого визуально).

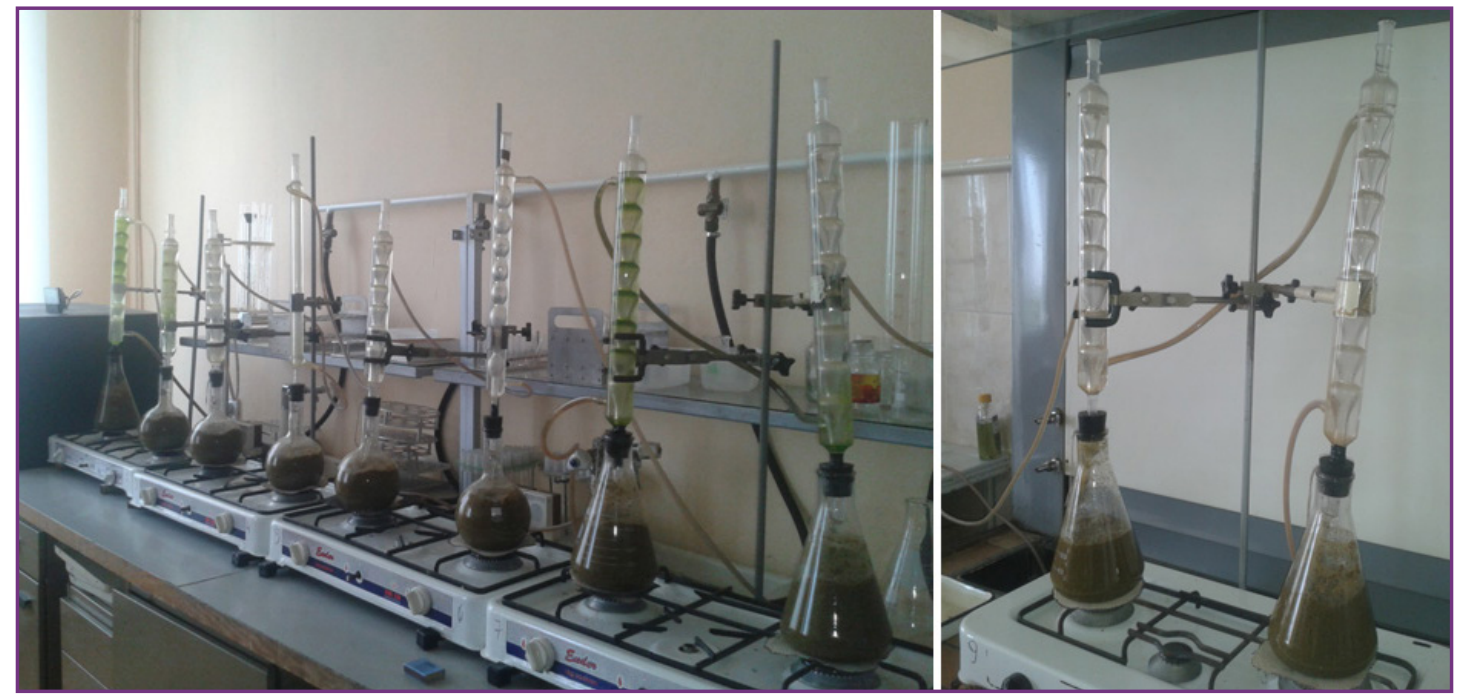

Рисунок 2 Экстракция эфирного масла из веточек и листьев Juniperus sabina L. (сухое растение) Figure 2 Extraction essential oil from twigs and leaves of Juniperus sabina L. (from dry row materials) 
Содержание эфирного масла в массо-объемных процентах $(X)$ в пересчете на абсолютно сухое сырье вычисляли по формуле 2:

$$
X=\frac{V \cdot 100 \cdot 100}{\alpha(100-W)^{\prime}}
$$

где: $\quad V$ - объем эфирного масла, мл; $\alpha$ - навеска сырья или лекарственного растительного препарата, в граммах; $W$ - влажность, \%

Математическую обработку полученных данных проводили согласно методу однофакторного дисперсионного анализа и расчету стандартного отклонения с использованием компьютерных методов обработки данных: пакет программ Microsoft Excel.

\section{Результаты и их обсуждение}

В результате сравнительного анализа полученных данных по экстракции эфирного масла из сухого и свежего растительного сырья при увеличении времени экстракции с часа до 2,5 часов (пошагово с интервалом в 30 минут) были получены статистически достоверные результаты. Обнаружено, что при экстрагировании из сухого сырья в течение часа, полутора и двух часов количество извлекаемого эфирного масла несущественно отличалось между собой - $p>0,05$ (табл. 1). В тоже время для свежего растения разница в извлеченной сумме через один час, полтора и два часа была существенна $(p \leq 0,05)$.

Таблица 1 Количество экстрагируемого эфирного масла из хвои - веточек и листьев Juniperus sabina L. в зависимости от продолжительности экстракции и влажности растительного материала

Table 1 The amount of extracted essential oil from needles - twigs and leaves (acerouse leaf) of Juniperus sabina L., depending on the duration of extraction and moisture of plant material

\begin{tabular}{|l|c|c|c|c|}
\hline \multirow{2}{*}{ Вариант } & \multicolumn{4}{|c|}{$\begin{array}{c}\text { Количество эфирного масла в зависимости от времени } \\
\text { экстракции в пересчете на } \mathbf{1 0 0} \text { г навески }\end{array}$} \\
\cline { 2 - 5 } & $\mathbf{1}$ час & $\mathbf{1 , 5}$ часа & $\mathbf{2}$ часа & $\mathbf{2 , 5}$ часа \\
\hline \multirow{2}{*}{$\begin{array}{l}\text { I. Высушенное растение } \\
\boldsymbol{W = 1 2} \%\end{array}$} & $1,30 \pm 0,06$ & $1,40 \pm 0,07$ & $1,45 \pm 0,07$ & $1,9 \pm 0,06$ \\
\hline \multirow{2}{*}{ II. Свежее растение $\boldsymbol{W = 6 5 \%}$} & $\mathrm{HCP}_{0,05}=0,094$ & $p>0,05$ & $\mathrm{HCP}_{0,05}=0,094$ & $p \leq 0,05$ \\
\cline { 2 - 5 } & $0,35 \pm 0,02$ & $0,50 \pm 0,07$ & $0,71 \pm 0,01$ & $1,00 \pm 0,07$ \\
\cline { 2 - 5 } & \multicolumn{4}{|c|}{$\mathrm{HCP}_{0,05}=0,075 p \leq 0,05$} \\
\hline
\end{tabular}

* разница существенна при $p \leq 0,05$; * differences are significant with $p \leq 0,05$

Установлено, что разница в количестве экстрагируемого эфирного масла (в массо-объемных процентах в пересчете на абсолютно сухое сырье) в первом варианте с высушенным растением между интервалами в один час и 1,5 часа составляет всего 7,7 \%, а между 1,5 и 2,0 часами - 10,5 \%. Тогда как во втором варианте со свежим растением эта же разница достигает 42,8 и 41,9 \% соответственно. Однако, при увеличении времени экстракции до 2,5 часов разница в количестве извлеченного масла существенна $(p \leq 0,05)$ как для свежего, так и для сухого растения. При этом в первом варианте при 2,5 часовой экстракции увеличение суммы экстрагированного эфирного масла по сравнению с 2,0 часами произошло на 31,0\%, а во втором варианте - на 40,9\% (рис. 3). 
Анализ полученных данных показал, что в течение первых полутора часов скорость экстракции выше в первом варианте с сухим сырьем по сравнению с экстракцией из свежего сырья (табл. 1, рис. 3).

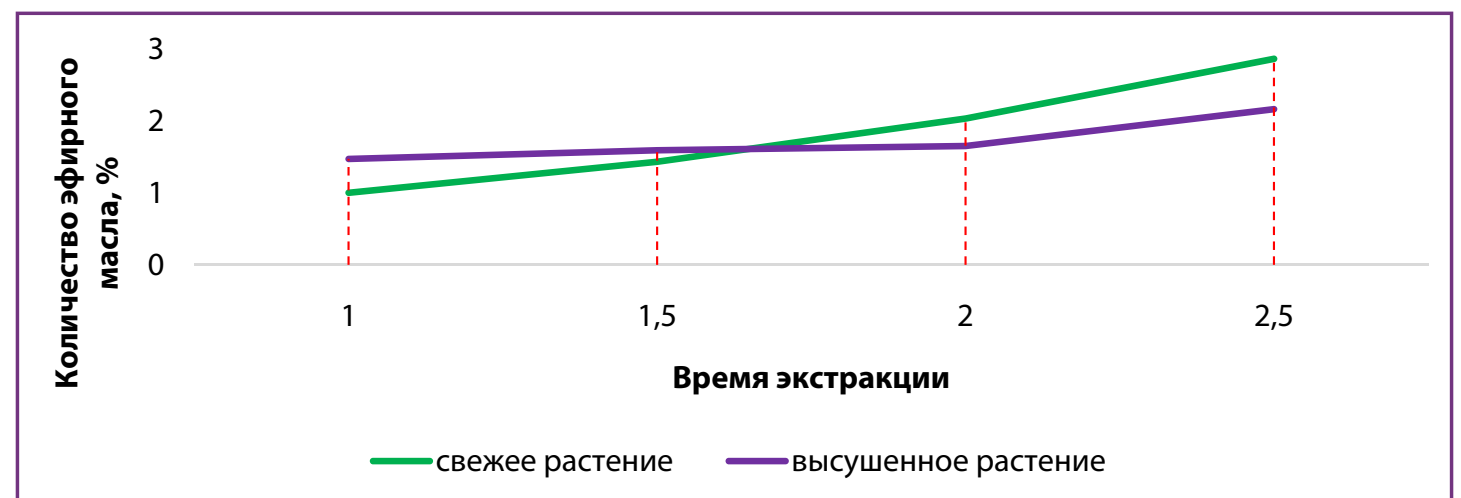

Рисунок 3 Количество экстрагируемого эфирного масла из свежего и высушенного растения Juniperus sabina L. (хвои), произрастающего в Республике Молдова, в пересчете на абсолютно сухой вес растения, в зависимости от продолжительности экстракции и влажности растительного материала (2017)

Figure 3 The amount of extracted essential oil from twigs and leaves of (needles) plant Juniperus sabina L. growing in the conditions of the Republic of Moldova, in terms of the absolutely dry weight of the plant, depending on the duration of extraction and moisture of the plant material (2017)

Согласно литературным данным экстракцию эфирного масла из можжевельника методом гидродистилляции рекомендуется проводить не менее, чем в течение двух часов (Новиков и др., 2014). Некоторые авторы (Уваровская, 2008) рекомендуют доводить время экстракции даже до 9 часов. Наши экспериментальные данные показали, что увеличение времени экстракции на каждые полчаса в течение первых двух часов дает существенную прибавку суммы экстрагируемого масла только в варианте со свежим материалом. В тоже время, в обоих вариантах количество эфирного масла существенно увеличилось через 2,5 часа от момента закипания смеси (рис. 3).

Статистический анализ данных показал, что из свежего растительного материала удается получить на 11,1 - 32,4 \% эфирного масла больше, чем из сухого сырья (в зависимости от продолжительности экстракции). В тоже время, следует отметить, что использование сухого сырья имеет ряд преимуществ. Во-первых, сушка дает возможность заготовить большое количество хорошо сохраняемого при комнатной температуре растительного сырья. Во-вторых, значительно облегчается процесс измельчения, потому что сухое сырье достаточно легко подвергается измельчению на различных мельницах (лабораторных, промышленных). Процесс измельчения свежего сырья до необходимых размеров вручную достаточно трудоемок и возможен не на всех типах мельниц, что существенно увеличивает себестоимость конечного продукта. По описанным выше причинам, считаем, что целесообразно все же в лабораторных условиях получение эфирного масла из сухого сырья методом гидродистилляции как минимум в течение 2,5 часов. Вопрос о том, насколько увеличивается выход масла при дальнейшем увеличении времени экстракции нуждается в дополнительной проверке. В результате из можжевельника казацкого, произрастающего в Молдове, нам удалось максимально извлечь до 1,1 \% эфирного масла в пересчете на абсолютно сухое сырье. 


\section{Выводы}

Таким образом установлено, что наименьшее рекомендуемое время для экстракции составляет 2,5 часа. Целесообразно после сбора проводить сушку растения для удешевления и автоматизации процесса измельчения материала. Конечный выход эфирного масла из растений вида Juniperus sabina произрастающего в условиях Республики Молдова, методом гидродистилляции при кипячении смеси в течение 2,5 часов составляет в среднем порядка 1,0 - 1,1\%.

\section{Благодарность}

Автор выражает благодарность сотрудникам и дирекции Института генетики, физиологии и защиты растений АНМ (Кишинев) за поддержку и неоценимую помощь в проведении научно-исследовательской работы; сотрудникам Ботанического сада АНМ, Института исследований и менеджмента лесных насаждений за помощь в идентификации растения Juniperus sabina L.; доценту, инженеру Яну Бриндзе и коллективу Института сохранения биоразнообразия и биологической безопасности Словацкого аграрного университета в Нитре за научную поддержку и предоставленную экспериментальную базу. Работа выполнена в рамках научной стажировки (application/contract number 51700164), поддержанной Международным Вышеградским Фондом (Братислава) - The International Visegrad Fund.

\section{Литература}

Adams, R.P. 2008. Junipers of the World: The genus Juniperus. $2^{\text {nd }}$ ed., Vancouver : Trafford Publ., 472 p. ISBN 978-1-4251-6879-7, 1425168795.

Adams, R.P. 2014. Junipers of the World: The Genus Juniperus. $4^{\text {th }}$ ed., Trafford Publishing. 415 p. ISBN-13 9781490723259. ISBN-10 1490723250.

Elisovetskaya, D., Nastas, T., Bucatel, V., Galupa, D. 2014. Natural crop protection based on plant resources of the Juniperus sabina L. in the Republic of Moldova. Conservation of Plant diversity. Int.Sc.Simp., ASM, Botanical Garden, UnASM. Chisinau: S.n., p. 88-89. ISBN 978-9975-62-370-4.

Farjon, A. 2005. A monograph of Cupressaceae and Sciadopitys. Kew Publishing, UK: Royal Botanic Gardens, Kew. ISBN 9781842460689.

Farjon, A. 2013. Juniperus sabina. The IUCN Red List of Threatened Species 2013: e.T42249A2966599. [online] 2017-08-05 [cit. 2017-08-05] Available at: http://dx.doi.org/10.2305/IUCN.UK.2013-1.RLTS.T 42249 A2966599.en

Hesham, H. A. Rassem, Abdurahman, H. Nour, Rosli, M. Yunus. 2016. Techniques for extraction of essential oils from plants: A Review. Australian Journal of Basic and Applied Sciences, vol. 10, no. 16, p. 117-127. ISSN1991-8178, EISSN 2309-8414.

Medicinal plants in Mongolia. 2013. @ World Health Organization. Western Pacific Region. ISBN 97892 90616320 (NLM Classification: QV 770 JM6). P. 95-96. [online] 2017-09-11 [cit. 2017-09-11] Available at: http://iris.wpro.who.int/bitstream/handle/10665.1/7839/9789290616320_eng.pdf

Nikolić, B., Vasiljević, B.; Mitić-Ćulafić, D., Lesjak, M., Vuković-Gačić, B., Mimica Dukić, N., Knežević-Vukčević, J. 2016. Screening of the antibacterial effect of Juniperus sibirica and Juniperus sabina essential oils in a microtitre platebased MIC assay. Botanica Serbica, vol. 40, no. 1, p. 43-48. DOI: 10.5281.zenodo.488858.

Schulz, C., Knopf, P., Stützel, T.H. 2005. Identification key to the Cypress family (Cupressaceae). Feddes Repertorium 116, Weinheim, 1-2, p. 96-146. DOI: 10.1002/fedr.200411062

Zhao, J., Liu T., Xu F., You S., Xu F., Li, C., Gu, Z. 2016. Anti-arthritic Effects of Total Flavonoids from Juniperus sabina on Complete Freund's Adjuvant Induced Arthritis in Rats. Pharmacogn Mag., vol. 12, no. 47, p. 178-183. DOI: 10.4103/0973-1296.186346 
Аёшина, Е.Н., Величко, Н.А. 2004. Исследования особенностей химического состава эфирных масел двух видов рода Juniperus. Химия растительного сырья. №4, 35-37. ISSN 1029-5143 (online).

Брагинец, Л.А. 2016. Интродукция некоторых древесных пород родов Thújа и Juníperus в дендрофлоре г. Костаная и его окрестностей. Электронный архив УГЛТУ. Леса России и хозяйство в них, № 1 (56), c. 40-47. ISSN 2218-7545.

Елисовецкая, Д.С., Настас, Т.Н., Одобеску, В.А. 2014. Возможность применения экстрактов из Juniperus sabina для защиты картофеля от колорадского жука. «Introduction, conversation and monitoring of plant diversity», Proceedings of the Intern. Scientific Conference for the $175^{\text {th }}$ anniversary of O.V.Fomin Botanical Garden of the Taras Shevchenko National University of Kyiv. Kyiv: Palivoda A.V., p. 240. ISBN 978-966-437-390-3.

Козак, Т.А. 1993. Биологические особенности видов рода можжевельник (Juniperus L.) в связи с использованием в декоративных насаждениях в Лесостепи Украины: дис. на здобуття наук. ступеня канд. біол. наук: НАН України. Центр. ботан. сад ім. М.М. Гришка: К., 173 с.

Мырзагалиева, А.Б.,Медеубаева, Б.3.2014.Кизучениюэфирномасличностипредставителейсемейства Cupressaceae Bartl. флоры Восточного Казахстана. Фундаментальные Исследования (Fundamental Research, The Publishing House «Academy of Natural History»), ИД «Академия Естествознания», № 5, часть 5, с. 1021-1024. ISSN 1812-7339.

Новиков, О.О., Писарев, Д.И., Жилякова, Е.Т., Трифонов, Б.В. 2014. Можжевельник: фитохимия и фармакология рода Juniperus L. Москва : Издательство PAMH. 177 с. ISBN 978-5-7901-0132-8.

Носов, А.М. 2001. Лекарственные растения. М.: Эксмо-Пресс. 350 с. ISBN 5040023146.

ОФС.1.5.3.0007.15 Определение влажности лекарственного растительного сырья. Министерство Здравоохранения Российской Федерации.

Писарев, Д.И. 2005. Фармакогностическое изучение можжевельника длиннохвойного и можжевельника казацкого : автореф. диссерт. на соиск. уч. степ. кандидат фармацевтических наук. Пятигорск. 146 с.

Семенютина, А.В., Свинцов, И.П., Хужатметова, А.Ш., Семенютина, В.А. 2014. Экологические аспекты культивирования и многоцелевого использования редких и исчезающих древесных видов природной флоры. Современная наука: Актуальные проблемы теории и практики. Серия «Естественные и Технические науки», № 11-12. [online] 2017-03-20 [cit. 2017-09-05] Available at: http://www.vipstd.ru/nauteh/index.php/ru/----etn14-11/1341-a

Уваровская, Д.К. 2008. Эфирные масла дальневосточных видов рода Juniperus L. (содержание, состав, использование) : автореф. дисс. на соиск. уч. степени к.б.н. Владивосток: ФГУ «ДальНИИЛХ». 34 с.

Щербаков, А.В, Усманов, И.Ю., Суюндуков, Я.Т. 2014. Популяционная изменчивость биосинтеза флавоноидов в лекарственных растениях Южного Урала. Известия Самарского научного чентра Российской академии наук, т. 16, № 1, с. 274-280. ISSN 1990-5378 (print). 